\title{
Effect of Heparin on Serum and Tissue Lipases in the Developing Rat
}

\author{
HADA ZAIDAN, ALISA GUTMAN, SUSAN BERKOW, PAUL HAMOSH, AND MARGIT HAMOSH \\ Department of Pediatrics and Department of Physiology and Biophysics, Georgetown University Medical Center, \\ Washington, D.C. 20007 and Department of Biochemistry, Hebrew University, Hadassah Medical School and \\ Hadassah University Hospital, Jerusalem, Israel [A.G.]
}

\begin{abstract}
The frequent inclusion of heparin in fluids used for total parenteral nutrition in infants, prompted an investigation of the ability of heparin to release lipoprotein lipase (LPL) and hepatic lipase (HL) from the endothelial surface into the circulation, and of the effect of heparin on tissue stores of lipase in the postnatal period. In rat pups, plasma postheparin lipolytic activity (PHLA) released by IP administration of heparin ( 0.5 unit/g body wt) was $15 \%$ of adult values at birth and increased rapidly to reach $60 \%$ on day 10. Repeated doses of heparin (in adult rats, given 0.1 unit/g IV) at 1 and $4 \mathrm{~h}$ after the initial dose did not affect the maximal response to heparin. In all age groups $80 \%$ of PHLA was inhibited by $0.5 \mathrm{M} \mathrm{NaCl}$, suggesting a mostly nonhepatic origin for the released enzyme. Heart, lung, and liver lipase activities of rat pups were not significantly different from controls not given heparin. The pattern of change in tissue enzyme content was similar for heart and lung, but different from hepatic lipase. LPL activity in the former increased from 10 and $30 \%$ to 60 and $100 \%$ of adult values between birth and 10 days while in the latter enzyme activity exceeded adult levels at birth and decreased to $50 \%$ of adult values during the latter half of the suckling period (days 10-21). Our results demonstrate that heparin does not cause depletion of tissue lipases in the postnatal period. The parallel increases in LPL content of peripheral tissues and PHLA suggest that in all age groups heparin-induced release of LPL into the circulation is proportional to tissue lipolytic activity. ( $\mathrm{Pe}$ diatr Res 18:1321-1324, 1984)
\end{abstract}

\section{Abbreviations}

PHLA, postheparin lipolytic activity LPL, lipoprotein lipase

FFA, free fatty acids

The first step in the catabolism of circulating triglycerides occurs at the luminal surface of the capillary endothelium where lipoprotein lipase (in extrahepatic tissues) and hepatic lipase (in the liver) hydrolyze lipoprotein-triglyceride to free fatty acids and monoglyceride $(10,21,22)$. The endothelial enzymes are readily released into the circulation after heparin injection (17), where they are referred to as PHLA. Numerous studies, in

Rèceived February 2, 1984; accepted June 11, 1984.

Correspondence may be addressed to Dr. Margit Hamosh, Department of Pediatrics, Georgetown University Medical Center, 3800 Reservoir Road NW, Washington, D. C. 20007.

This study was supported by National Institutes of Health Grant HD-15631. isolated organs or intact animals, have shown that the easily accessible endothelial enzyme is directly related to triglyceride hydrolysis; its removal from the endothelium following heparin infusion completely abolishes the ability of isolated organs to hydrolyze infused lipoprotein-triglyceride $(9,21)$, whereas injection of antibodies against lipoprotein lipase is rapidly followed by marked hyperlipemia $(1,16)$. Thus, serum postheparin lipolytic activity provides an accurate measure of functional (endothelial) lipase concentrations. Since serum postheparin lipolytic activity is easily accessible, it has been extensively studied in humans $(4,6,10)$, whereas animal studies have been limited mainly to adults.

PHLA increasès with gestational age; it is low in low birth weight premature infants (8), as compared to term infants (14). The developmental pattern of PHLA is of importance for the clinical management of very low birth weight infants, who are maintained on total parenteral nutrition containing Intralipid as the major energy source (23). Some nurseries routinely include heparin ( $1 \mathrm{unit} / \mathrm{ml})$ in total parenteral nutrition solutions given to low birth weight infants. Since little is known about the long term effects of Intralipid in neonates and about the possible effects of heparin administration on tissue stores of lipid-clearing enzymes, we studied the effect of heparin on tissue lipase stores and on their release from the endothelial surface into the circulation. Since these tissue enzymes cannot be studied in humans, we measured postheparin lipolytic activity and the effect of heparin on lipoprotein lipase and hepatic lipase in the developing rat.

\section{MATERIALS AND METHODS}

Animals. Pregnant Sprague-Dawley rats were observed daily to determine the date of birth of the litters. The mothers and pups had free access to food throughout the experiment. The pups were studied at birth and at $3,10,14,17,21,28$, and 60 days. At 21 days after birth, the pups were separated from their mothers and the males and females were housed separately.

Administration of heparin to rats ages 1-28 days was by the IP route since it was technically difficult to give IV injections to very young animals. Following preliminary experiments, a dose of 0.5 unit/g body wt was chosen; with this dose, there was little or no bleeding, whereas smaller doses produced lower responses. Preliminary studies in weanling pups (days 21 and 28) have shown comparable levels of PHLA following heparin administration by either IP or IV route. The animals were sacrificed by decapitation and blood was collected from cervical vessels. For experiments on older rats, 0.1 unit heparin/g body wt was given IV under pentobarbital anesthesia $(50 \mathrm{mg} / \mathrm{kg})$, and blood was obtained from the tail vein or from the bifurcation of the aorta at the time of sacrifice. For lipase assay on tissues, the hearts, lungs, and livers were dissected, rinsed in ice-cold saline, and 
weighed before being homogenized in $0.025 \mathrm{M} \mathrm{NH}_{3}-\mathrm{HCl}$ buffer containing heparin, 4 units $/ \mathrm{ml}$. The stomachs were checked for the presence of food and weighed to ensure that all pups were fed. Organs weighing under $1 \mathrm{~g}$ were minced and used in their entirety, those weighing above $1 \mathrm{~g}$ were minced, and $1.0 \mathrm{~g}$ was taken for homogenization. Acetone powders were prepared as previously described (11).

Assays of lipolytic activities. The acetone powders were solubilized by rehomogenization in cold $0.025 \mathrm{M} \mathrm{NH}_{3}-\mathrm{HCl}$ buffer, pH 8.1, containing heparin, 4 units $/ \mathrm{ml}$. The lipolytic activities in both plasma and acetone powders were measured by hydrolysis of serum-activated tri ${ }^{3} \mathrm{H}$ ]oleate as previously described (9), and expressed as $\mu \mathrm{mol} \mathrm{FFA} \mathrm{produced} / \mathrm{ml} / \mathrm{h}$ for plasma and $\mathrm{nmol}$ FFA produced $/ \mathrm{mg}$ acetone powder/h for the tissues. The quantitative contribution of hepatic lipase and lipoprotein lipase to total PHLA was measured by assay of lipase activity in the presence or absence of $0.5 \mathrm{M} \mathrm{NaCl}$. High ionic strength (achieved by $0.5 \mathrm{M} \mathrm{NaCl}$ ) completely inhibits lipoprotein lipase, but has no effect on the activity of hepatic lipase (17).

Statistical differences between groups were evaluated by Student's $t$ test.

\section{RESULTS}

The time course of PHLA release after IP heparin administration to pups ages 3-17 days is presented in Figure 1. Peak lipase activity was at $30 \mathrm{~min}$ after heparin administration with a return to baseline after $4 \mathrm{~h}$, and was higher with increasing age.

Total PHLA increased rapidly between birth and 10 days of age and did not show further significant changes up to 28 days (Fig. 2). The increase in PHLA activity between 28 and 60 days of age is probably associated with the marked increase in adipose tissue size, an organ rich in lipoprotein lipase. In all age groups, $80 \%$ of the lipolytic activity released into the circulation was inhibited by $0.5 \mathrm{M} \mathrm{NaCl}$ and can, therefore, be presumed to be of peripheral origin. The marked increase in heparin-releasable hepatic lipase between 28 and 60 days after birth (Fig. 2) is probably directly related to the 3 -fold increase in hepatic lipase activity during this period (Fig. $4 C$ ). No lipolytic activity was detected in plasma of rats not given heparin.

To assess the rate of replenishment of endothelial lipoprotein lipase after its release by injection of heparin into the circulation, we measured the level of PHLA after repeated bolus heparin injections. In 60-day-old rats given heparin IV (0.10 unit/g),

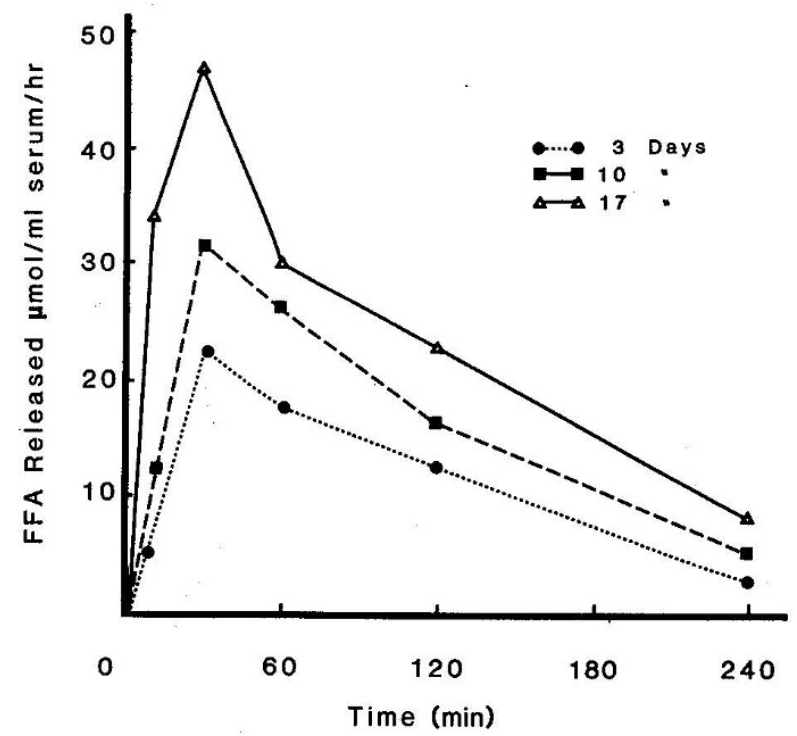

Fig. 1. Time course of lipase release into the circulation after bolus injection of heparin (IP, $0.5 \mathrm{unit} / \mathrm{g}$ ) in suckling rats ages 3,10 , and 17 days. Data are mean values from three animals for each time point tested.

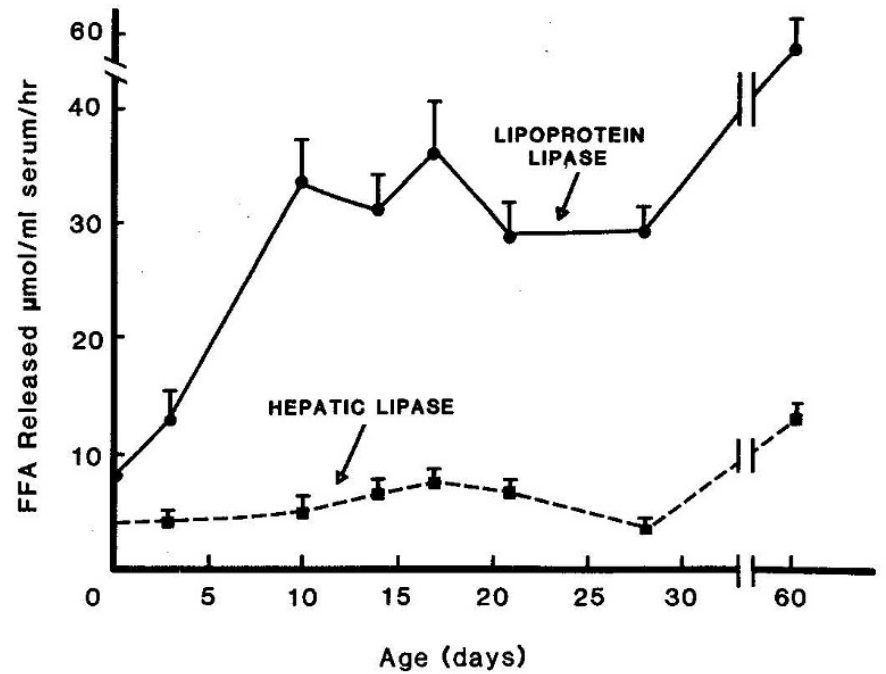

Fig. 2. Peak postheparin lipolytic activity from birth to 28 days of age. Data are mean $\pm \mathrm{SE}$ of seven animals at each time point. lipoprotein lipase (activity completely inhibited by $0.5 \mathrm{M} \mathrm{NaCl}$ ); $\square--$, hepatic lipase (activity not inhibited by $0.5 \mathrm{M} \mathrm{NaCl}$ ).

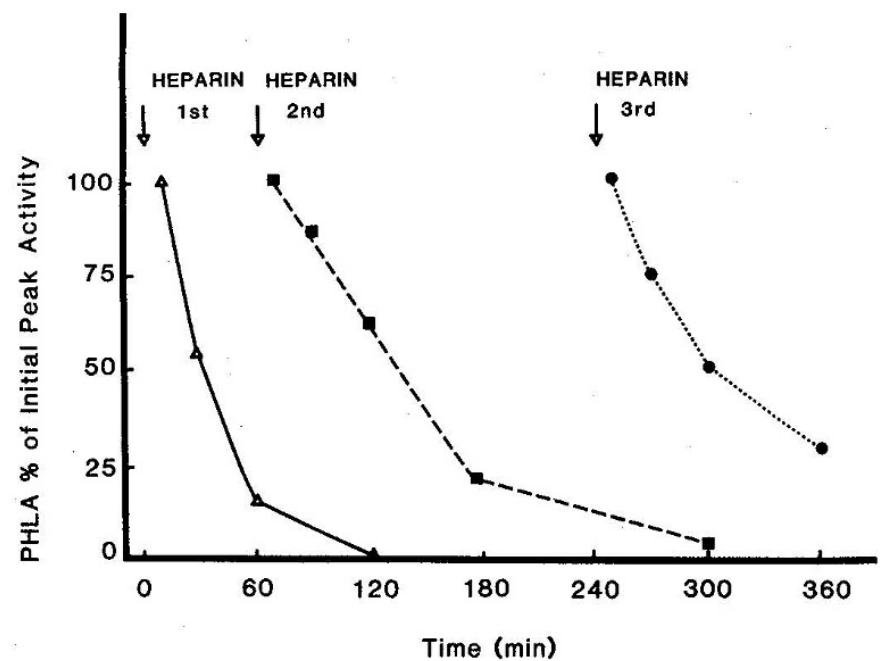

Fig. 3. Effect of repeated heparin administration $(0.1 \mathrm{unit} / \mathrm{g}$ IV) on peak postheparin lipolytic activity levels. Blood was obtained from the tail vein at each time point studied. PHLA was quantitated in $20 \mu \mathrm{l}$ serum as described previously (9). The data are means of three experiments. Mean initial PHLA level was $53 \mu \mathrm{mol} \mathrm{FFA} \mathrm{released} / \mathrm{ml}$ serum $/ \mathrm{h}$ (range, 40-58 $\mu \mathrm{mol}$ FFA released $/ \mathrm{ml}$ serum $/ \mathrm{h}$ ). For each experiment, PHLA was measured for $2 \mathrm{~h}$ after the first bolus heparin injection, for 4 $\mathrm{h}$ after the second bolus heparin, and for $1 \mathrm{~h}$ after the last bolus heparin administration. The end point for each heparin administration given is the result of data obtained on the first part of the study. The same group of animals were studied $24 \mathrm{~h}$ later, when bolus heparin was given at zero time (first) and 1 and $4 \mathrm{~h}$ after the first heparin administration. The halflife of circulating lipase increased from $30.6 \mathrm{~min}$ after the first bolus of heparin to $65.5 \mathrm{~min}$ after a second bolus of heparin given $60 \mathrm{~min}$ after the first injection. After a third bolus of heparin, given $4 \mathrm{~h}$ after the first bolus, the half-life of lipase in the circulation was $70 \mathrm{~min}$.

maximum PHLA release ( $53 \mu \mathrm{mol}$ FFA released/ml serum $/ \mathrm{h}$ ) occurred $10 \mathrm{~min}$ after IV administration of heparin. The peak response to repeated heparin administration at 1 and $4 \mathrm{~h}$ was similar to that elicited by the initial heparin dose. A noteworthy effect of the repeated administration of heparin was the marked increase in the half-life of the enzyme in the circulation from 30 to $70 \mathrm{~min}$ (Fig. 3).

There was no significant difference between lipase levels in the 
tissues of animals receiving heparin and of controls (Fig. 4, $A, B$, and $C$ ). The pattern of changes in lipase activity of lung and heart (Fig. 4, $A$ and $B$ ) was similar to that of PHLA, i.e. low at birth, with an increase to adult levels by day 10 . At birth, lipase activity of the liver (Fig. $4 C$ ) was higher than in the adult and did not change markedly during the first 10 days. During the latter part of the suckling period there was a sharp decline in the specific activity of liver lipase to $30 \%$ of adult values and a more moderate decrease in the activities of the lung and heart enzymes. Calculation of lipolytic activity for the whole organ, based on tissue weight (Table 1), shows that there was an absolute decrease in hepatic and pulmonary lipolytic activity of 50 and $20 \%$, respectively. The decrease in the specific activity of heart lipase was compensated for by the increase in weight occurring during the same period.

\section{DISCUSSION}

The developmental pattern of lipoprotein lipase and hepatic lipase in the rat has been studied by several investigators $(5,7$, $11-13,19,20)$. We have, however, no information on postheparin lipolytic activity levels in the developing rat. A better un-

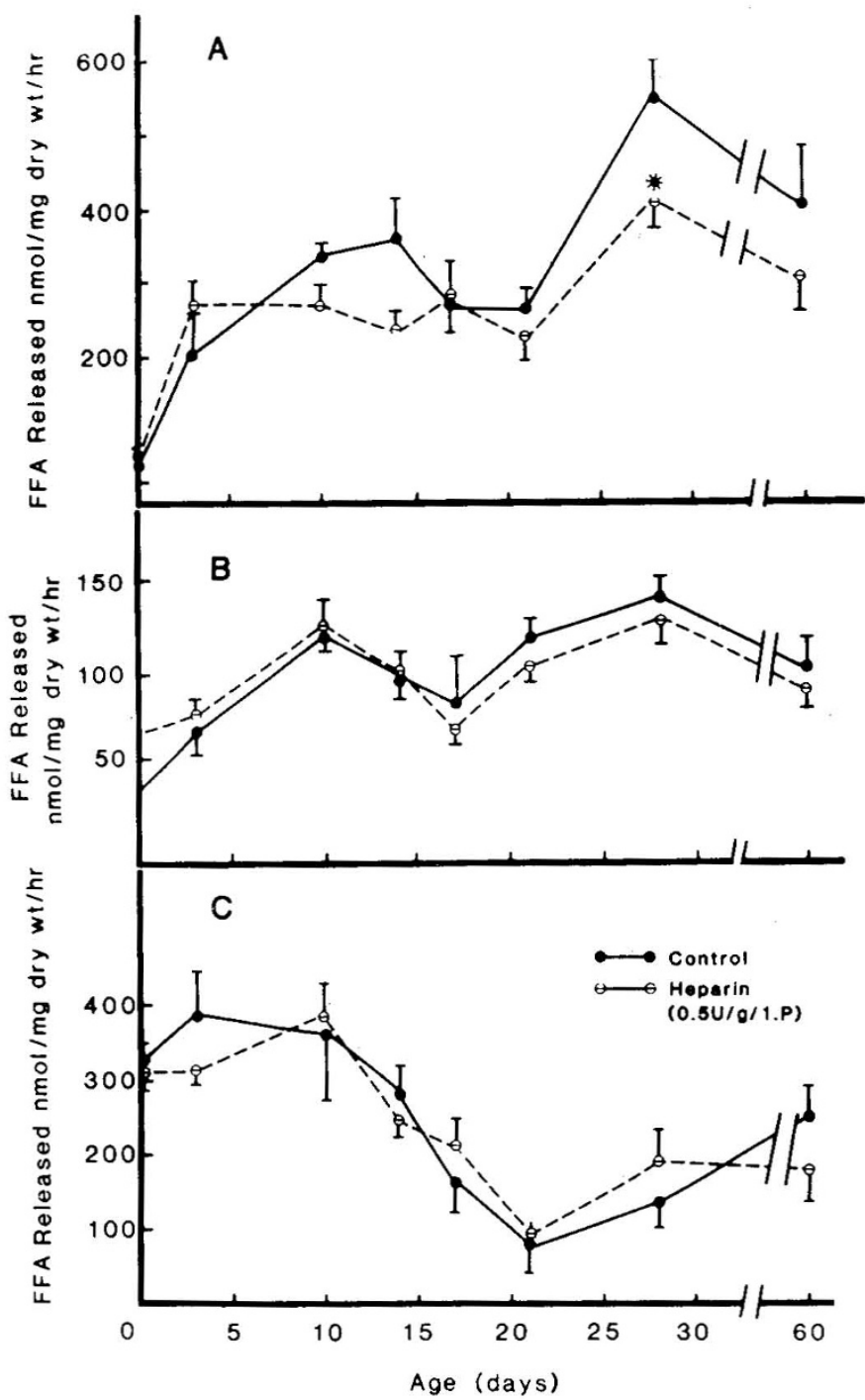

Fig. 4. Effect of heparin administration on tissue levels of lipase in heart $(A)$, lung $(B)$, and liver $(C)$ of developing rats. $-\longrightarrow$, control

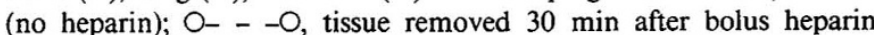
injection $(0.5 \mathrm{unit} / \mathrm{g}$ IP to rats ages $0-28$ days, and $0.1 \mathrm{unit} / \mathrm{g}$ IV to rats age 60 days). Data are mean \pm SE of seven animals for each time point. ${ }^{*} p<0.05$.
Table 1. Body and organ weights during postnatal development in the rat*

\begin{tabular}{ccccc}
\hline $\begin{array}{c}\text { Age } \\
(\text { days })\end{array}$ & $\begin{array}{c}\text { Body weight } \\
(\mathrm{g})\end{array}$ & $\begin{array}{c}\text { Heart } \\
(\mathrm{mg})\end{array}$ & $\begin{array}{c}\text { Lung } \\
(\mathrm{mg})\end{array}$ & $\begin{array}{c}\text { Liver } \\
(\mathrm{g})\end{array}$ \\
\hline 0 & $5.8 \pm 0.11$ & $48.9 \pm 1.65$ & $102.1 \pm 2.63$ & $0.29 \pm 0.005$ \\
3 & $10.7 \pm 0.25$ & $75.1 \pm 2.93$ & $214.2 \pm 6.10$ & $0.38 \pm 0.006$ \\
7 & $15.0 \pm 0.29$ & $97.1 \pm 2.33$ & $286.3 \pm 5.98$ & $0.44 \pm 0.013$ \\
10 & $18.6 \pm 0.48$ & $110.3 \pm 1.88$ & $349.4 \pm 10.91$ & $0.57 \pm 0.018$ \\
14 & $27.6 \pm 0.35$ & $127.0 \pm 0.89$ & $367.1 \pm 5.22$ & $0.83 \pm 0.016$ \\
17 & $34.5 \pm 0.44$ & $177.5 \pm 4.44$ & $412.8 \pm 8.11$ & $1.05 \pm 0.012$ \\
21 & $39.4 \pm 0.48$ & $219.1 \pm 3.97$ & $361.0 \pm 4.09$ & $1.50 \pm 0.044$ \\
28 & $73.3 \pm 1.36$ & $305.6 \pm 5.14$ & $479.3 \pm 6.41$ & $3.49 \pm 0.095$ \\
60 & $271.4 \pm 20.10$ & $884.4 \pm 70.90$ & $1259.6 \pm 99.3$ & $12.29 \pm 0.887$ \\
\hline
\end{tabular}

* All values are means $\pm \mathrm{SE}$ of 10 determinations at each age.

derstanding of the effect of heparin on the relationship between endothelial and parenchymal lipase levels during postnatal development is essential for the clinical management of newborn infants maintained on total parenteral nutrition that often contains low levels of heparin ( 1 unit/ml). Because tissue specimens have to be analyzed, this question has to be answered by animal studies.

The aim of our study was, therefore, to measure the levels of heparin releasable lipase (PHLA) in the suckling rat, to assess to what extent removal of the endothelial enzyme affects tissue levels of lipoprotein lipase and hepatic lipase, and whether repeated administration of heparin might deplete tissue stores and lower endothelial enzyme levels, and thus impair the clearing of circulating triglycerides. We have chosen the heart, lung, and liver for quantitation of tissue lipase levels before and after heparin injection, because these are well defined organs in which total lipase activity can be measured. Such measurements cannot be obtained in adipose tissue or muscle because of the diffuse nature of these tissues.

Our study shows that, from birth on, endothelial lipase can be released into the circulation by heparin administration and that, as previously shown in the adult, no lipase is present in the circulation prior to heparin administration. Peak postheparin lipolytic activity increased rapidly from birth to midsuckling (Fig. 2). This developmental pattern of PHLA follows closely that of the enzyme in the extrahepatic tissues studied. A further increase in heparin-releasable lipases occurs after weaning and is probably associated with the marked increase in adipose tissue, an organ rich in lipoprotein lipase $(5,11,12)$. The data presented in Figure 4 show no difference in total lipase content of heart, lung, and liver after heparin administration, suggesting that the lipase present at the endothelium amounts to only a small percentage of total tissue lipase, or that enzyme synthesis rapidly replenishes the amount released into the circulation. Studies with isolated cells that contain lipoprotein lipase show that heparinstimulated release of enzyme into the medium markedly increases the synthesis of lipoprotein lipase in the cells. Indeed, repeated bolus heparin administration $(0.1 \mathrm{unit} / \mathrm{g})$ to adult rats led to almost identical peak postheparin lipolytic activity levels, indicating that replenishment of the endothelial sites was complete within $1 \mathrm{~h}$ after the initial release of lipoprotein lipase into the circulation. The increase in the half-life of the circulating enzyme, after repeated bolus heparin injection, is probably due to higher circulating levels of heparin, which have been shown to protect the lipase from breakdown in the liver $(15,24)$.

Lipase activities in the lung and heart increased rapidly after birth, reached a peak at about midsuckling and declined at weaning before increasing to adult levels. Liver lipase, which at birth was above adult levels, showed an even greater decline in the preweaning period. A similar developmental pattern has been reported earlier for several organs in the rat $(5,11,13)$. The decline of activity at weaning may be associated with hormonal changes that occur at this period $(2,3)$ or with the sudden change in food composition. Hepatic lipase activity rises again after 
weaning, the level of activity increasing almost 3-fold between 28 and 60 days of age.

Our finding in the developing rat, that the release of endothelial lipoprotein lipase and hepatic lipase to the circulation following heparin injection does not lower the tissue enzyme concentrations, might be relevant to the clinical management of preterm infants. Very low birth weight infants (gestational age, 25-30 wk) often have to be kept on total parenteral nutrition containing Intralipid (a stable soybean oil emulsion) as the main energy source. We have recently shown that when the IV fluids contain low levels of heparin (1 unit/ml heparin added to prevent clotting of catheters), there are measurable levels of circulating lipase that might be associated with more efficient clearing of the Intralipid (25). Our animal studies suggest that even higher amounts of heparin do not cause a significant depletion of tissue lipase stores. Furthermore, in the adult, the endothelial sites are rapidly replenished after initial release of lipoprotein lipase to the circulation. Whether the rate of endothelial lipase replenishment is similar in the newborn remains to be established.

\section{Acknowledgment. We thank Ms. Marguerite Starry for skillful} secretarial help.

\section{REFERENCES}

1. Behr SR, Patsch JR, Forte T, Bensadoun A 1981 Plasma lipoprotein changes resulting from immunologically blocked lipolysis. J Lipid Res 22:443

2. Blasquez E, Lipshaw LA, Blasquez M, Foa PP 1975 The synthesis and release of insulin in fetal, nursing and young adult rat: studies in vivo and in vitro. Pediatr Res 9:17

3. Blasquez E, Sugase T, Blasquez M, Foa PP 1974 Neonatal changes in the concentration of rat liver cyclic AMP and of serum glucose, free fatty acids, insulin, pancreatic and total glucagon in man and in the rat. J Lab Clin Med 83:957

4. Borensztajn J 1979 Lipoprotein lipase. In: Scanu RW, Wissler RW, Getz GS (eds) Biochemistry of Atherosclerosis, Biochemistry of Disease, Vol 7. Marcel Dekker, New York, p 231

5. Chajek T, Stein O, Stein Y 1977 Pre-and post-natal development of lipoprotein lipase and hepatic triglyceride hydrolase activity in rat tissues. Atherosclerosis
26:549

6. Cryer A 1981 Tissue lipoprotein lipase activity and its action in lipoprotein metabolism. Int J Biochem 13:525

7. Das JB, Joshi ID, Philippart AI 1982 Postnatal development of lipid clearing enzymes in the suckling animal. J Pediatr Surg 17:914

8. Dhanireddy R, Hamosh M, Sivasubramanian KN, Chowdhry P, Scanlon JW, Hamosh P 1981 Postheparin lipolytic activity and Intralipid clearance in very low birth weight infants. J Pediatr 98:617

9. Gal S, Bassett DPJ, Hamosh M, Hamosh P 1982 Triacylglycerol hydrolysis in the isolated perfused rat lung. Biochim Biophys Acta 713:222

10. Hamosh M, Hamosh P 1983 Lipoprotein lipase: its physiological and clinical significance. Mol Aspects Med 6:199

11. Hamosh M, Simon MR, Canter H Jr, Hamosh P 1978 Lipoprotein lipase activity and blood triglyceride levels in fetal and newborn rats. Pediatr Res 12:1132

12. Hietanen E, Greenwood MRC 1977 A comparison of lipoprotein lipase activity and adipocyte differentiation in growing male rats. $J$ Lipid Res 18:480

13. Hietanen E, Hartiala $\mathbf{J} 1979$ Developmental pattern of pulmonary lipoprotein lipase in growing rats. Biol Neonate $36: 85$

14. Hogstedt B, Lindquist B 1963 Lipoprotein lipase in the plasma of the normal newborn. Acta Paediatr 52:61

15. Iverius PH, Lindahl U, Egelrud T, Olivecrona T 1972 Effects of heparin on lipoprotein lipase from bovine milk. J Biol Chem 247:6610

16. Kompiang IP, Bensadoun A. Yang MWW 1976 Effect of an anti-lipoprotein lipase serum on plasma triglyceride removal. J Lipid Res 17:498

17. Krauss RM, Windmuller HG, Levy RI, Fredrickson DS 1973 Selective measurement of two different triglyceride lipase activities in rat post heparin plasma. J Lipid Res 14:286

18. Llobera M, Montes A, Herrera E 1979 Lipoprotein lipase activity in liver of the rat fetus. Biochem Biophys Res Commun 91:272

19. Matsuo M, Nakamura H, Yamasaki T, Mimasu S, Matsuo T 1980 Development of lipoprotein lipase in rat lung. Kobe J Med Sci 26:229

20. Planche E, Boulange A, DeGasquet $P$, Tonnu NT 1980 Importance of muscle lipoprotein lipase in rats during suckling. Am J Physiol 238:E511

21. Scow RO, Hamosh M, Blanchette-Mackie EJ, Evans AJ 1972 Uptake of blood triglyceride by various tissues. Lipids 7:497

22. Scow RO, Blanchette-Mackie EJ, Smith LC 1977 Role of capillary endothelium in the clearance of chylomicrons. A model for lipid transport from blood by lateral diffusion in cell membranes. Circ Res 39:149

23. Vretlind A 1981 Development of fat emulsions. JPEN 5:230

24. Wallinder L, Bengtsson G, Olivecrona T 1979 Rapid removal to the liver of intravenously injected lipoprotein lipase.-Biochim Biophys Acta 575:166

25. Zaidan H, Dhanireddy R, Hamosh M, Pramanik AK, Chowdhry P, Hamosh P 1982 Effect of continuous heparin administration on Intralipid clearing in very low birth weight infants. J Pediatr 101:599 